\title{
A Comparison of the Greenhouse Gas Emissions From the Sheep Industry With Beef Production in Canada
}

\author{
James A. Dyer ${ }^{1}$, Xavier P. C. Vergé ${ }^{2}$, Raymond L. Desjardins ${ }^{3} \&$ Devon E. Worth ${ }^{3}$ \\ ${ }^{1}$ Agro-environmental Consultant, 122 Hexam Str., Cambridge, Ontario, Canada \\ ${ }^{2}$ Consultant to AAFC, Ottawa, Ontario, Canada \\ ${ }^{3}$ Agriculture and Agri-Food Canada, 960 Carling Avenue, Ottawa, Ontario, Canada \\ Correspondence: James A. Dyer, Agro-environmental Consultant, 122 Hexam Str., Cambridge, Ontario, Canada. \\ Tel: 1-519-653-2995. E-mail: jamesdyer@sympatico.ca
}

Received: January 21, 2014 Accepted: May 13, 2014 Online Published: June 25, 2014

doi:10.5539/sar.v3n3p65 URL: http://dx.doi.org/10.5539/sar.v3n3p65

\begin{abstract}
Sheep production in Canada is a small industry in comparison to other livestock systems. Because of the potential for expansion of the sheep industry in Canada, the GHG emissions budget of this industry was assessed in this paper. The GHG emissions from Canadian lamb production were compared with those from the Canadian beef industry using the ULICEES model. The GHG emission intensity of the Canadian lamb industry was $21 \%$ higher than lamb production in France and Wales, and 27\% higher than northern England. Enteric methane accounts for more than half of the GHG emissions from sheep in Canada. The protein based GHG emission intensity is $60 \%$ to $90 \%$ higher for sheep than for beef cattle in Canada. The GHG emission intensity for sheep in Eastern Canada is higher than for sheep in Western Canada. Protein based GHG emission intensity is more sensitive to the difference between sheep and beef than LW based emission intensity. This paper demonstrated that protein based GHG emission intensity is a more meaningful indicator for comparing different livestock species than live weight (LW) based GHG emission intensity.
\end{abstract}

Keywords: sheep, lambs, beef, greenhouse gas emissions, carbon footprint, livestock crop complex, protein, live weight

\section{Introduction}

In Canada the main livestock-based industries are beef, pork, dairy, eggs and poultry. In comparison to beef and pork, sheep-based products play only a minor role in the Canadian agri-food sector (Statistics Canada, 2009). Consequently, Canada's contribution to the global market for lamb is very small (Walker, 2008). The small size of the Canadian sheep population, the low volume of exports and the growing global demand for protein suggest an opportunity to expand the sheep industry in Canada. Impending climate change will introduce more variability to food production (Bonatti, Schlindwein, de Vasconcelos, Sieber, \& D'Agostini, 2013). It is important for land use policies, including livestock, to be diverse and to leave a minimal carbon footprint. Since both beef cattle and sheep are ruminants, the carbon footprint of sheep production can be defined most effectively by using the beef industry as a benchmark (Edwards-Jones, Plassmann, \& Harris, 2009). Whether the current approach to raising sheep in Canada, which is relatively intensive, has a greater GHG emission intensity than beef production needs to be determined. If this was found to be true, then, from the perspective of GHG emissions, the land needed to expand sheep would be better used to support additional beef cattle.

In addition to being the largest livestock industry in Canada, and the largest agricultural emitter of Greenhouse Gases (GHG) (Vergé et al., 2012), beef production is the most GHG-intensive source of protein of Canada's five major livestock industries (Dyer, Desjardins, \& Worth, 2010a). Considerable information is available regarding the GHG emissions from the Canadian beef industry (Beauchemin, Janzen, Little, McAllister, \& McGinn, 2010; Desjardins et al., 2012; Vergé, Dyer, Desjardins, \& Worth, 2008a). Unlike the grain-fed hogs and poultry, the reliance of beef production on roughages makes enteric methane a major term in the GHG emissions budget of beef cattle (Capper, 2012; IPCC, 2006). There is currently no effective mitigation for enteric methane emissions (Cottle, Nolan, \& Wiedemann, 2011). However, there is widespread dependence on feedlot operations in both the Canadian and U.S. beef industries, where more grain in the cattle diet reduces the intensity of enteric methane 
emissions (Capper, 2012; Vergé et al., 2008a).

Quantifying the GHG emissions from the Canadian sheep industry was the main goal of this paper. The other agro-ecological benefits were excluded from this assessment. The GHG emissions budget of sheep was determined using the Unified Livestock Industry and Crop Emissions Estimation System (ULICEES) described by Vergé et al. (2012). Comparing the carbon footprints of the Canadian beef and lamb industries was the second goal of this paper. Since ULICEES has already been applied to the Canadian beef industry, it facilitated a comparison of this industry with the Canadian beef industry on the same computational basis. To verify that ULICEES was an appropriate model for Canadian sheep production, the GHG emissions budget of sheep was compared to several offshore national sheep industry GHG emission estimates.

\section{Background}

Although these two grazing animals have fundamentally different mouth parts (OMAFRA, 2011) and differ in their preference for the type of forage they eat (Van Dyne, Brockington, Sxocs, Duek, \& Ribic, 1980), they are both ruminants and emit enteric methane. The dryness of sheep manure compared to beef cow manure (ASAE, 2003 ) is an important difference between these two ruminants because manure storage is the source of two important types of GHG (Vergé et al., 2012). The storage of dry manure produces large emissions of $\mathrm{N}_{2} \mathrm{O}$ while storage of liquid manure produces large emissions of $\mathrm{CH}_{4}$ (Janzen, Desjardins, Rochette, Boehm, \& Worth, 2008). Since sheep manure that is not directly deposited in the pasture is managed mainly by dry storage, emissions of $\mathrm{N}_{2} \mathrm{O}$ are the main concern.

While the need for domestic wool made sheep an integral part of Canada's early farming history (CCWG, 2011), easier management has made cattle the dominant farm animal on prairie grazing lands (Vergé et al., 2012). The resulting reduction in sheep numbers coincided with the spread of invasive weeds on western rangelands (Walker, Coffey, \& Faller, 2006). Since sheep eat weeds such as leafy spurge, which are toxic to cattle, it has been suggested that producers could use these animals for non-chemical weed control (SMA, 2008).

\section{Methodology}

Since ULICEES has been described in detail elsewhere (Vergé et al., 2012), this section presents only the main concepts used and the adaptations needed for the sheep industry. ULICEES was created by assembling the four groups of livestock-specific GHG computations from the Canadian beef, dairy, pork and poultry industries (Vergé, Dyer, Desjardins, \& Worth, 2007, 2008a, 2008b, 2009) in one spreadsheet model. As well as the direct emissions from livestock, these calculations account for GHG emissions from the crop complex that is used to feed each livestock population, and manure characteristics and storage practices of each livestock type. The ULICEES model accounted for the $\mathrm{N}_{2} \mathrm{O}$ emissions from sheep manure which was mainly handled as dry manure. Because 2001 was the most recent year with livestock diet survey data (Elward, McLaughlin, \& Alain, 2003), ULICEES was initially applied to 2001 (Vergé et al., 2012). For this analysis, however, ULICEES was updated to 2006, the closest census year to the mid-point of the 2000-2009 study period used in the sheep report for Canada (Statistics Canada, 2009). This update of ULICEES had to allow for the changes in tillage practices, crop areas, fertilizer applications and livestock populations.

\subsection{Modeling the GHG Budget of Canadian Sheep}

To take into account the complete lifecycle of meat animals, ULICEES calculates the GHG emissions from all age-gender categories of each type of Livestock. The age-gender categories used in ULICEES for sheep in the present study were mature breeding animals (ewes and rams), breeding (replacement) lambs and market lambs (Statistics Canada, 2003). The livestock GHG assessments include fossil $\mathrm{CO}_{2}, \mathrm{CH}_{4}$ and $\mathrm{N}_{2} \mathrm{O}$ emissions. Emissions of $\mathrm{CH}_{4}$ and $\mathrm{N}_{2} \mathrm{O}$ were distributed over age-gender categories within each livestock type based on differences in feed intake and live weight (LW).

\subsubsection{Methane Emissions}

Emissions from enteric fermentation and manure storage were calculated on a per-head basis using the ULICEES model (Vergé et al., 2012) which relies on IPCC Tier 2 methodology (IPCC, 2006). Because the two sources require different management, ULICEES quantified manure methane separately from enteric methane. Both types of methane emissions from each age-gender category were multiplied by each respective category population.

\subsubsection{Nitrous Oxide Emissions}

ULICEES also uses the Tier 2 methodology from IPCC (2006), modified for Canadian conditions by Rochette et al. (2008), to estimate nitrous oxide emissions. For sheep, nitrogen $(\mathrm{N})$ excretion rates were based on Dry Matter 
Intake (DMI) (Vergé et al., 2012). The Canadian DMI average values (Marinier, Clark, \& Wagner-Riddle 2004) were indexed to the average animal weights for the two regions and the age-gender categories before being integrated over the population in each age-gender category.

\subsubsection{Carbon Dioxide Emissions}

The fossil $\mathrm{CO}_{2}$ emissions budget for livestock in ULICEES was based on the six farm energy terms defined by Dyer and Desjardins (2009). Provincial fossil $\mathrm{CO}_{2}$ emission rate estimates for these six energy terms for 2006 provided by Dyer, Desjardins, McConkey, Kulshreshtha, and Vergé (2013) were incorporated into ULICEES. The farm fieldwork term and fertilizer and machinery supply energy terms were extrapolated from the energy use for all field crops according to Dyer and Desjardins (2009) based on the complex of crop land that supports the sheep industry. The three indirect energy terms, on-farm transport, heating fuels and electricity, could not be related to the livestock crop complexes (Dyer et al., 2013). Instead they were taken from the 1996 Farm Energy Use Survey (FEUS) reported by CAEEDAC (2001). The sheep to beef cattle ratio of total LW was used to scale the FEUS energy quantities for beef to the sheep population because the Canadian sheep industry was too small to be treated as a separate farm type in the FEUS (CAEEDAC, 2001).

\subsection{Sheep Crop Complex}

The livestock crop complex concept was used in the four previous livestock GHG emission budgets in Canada (Dyer, Vergé, Desjardins, \& Worth, 2008; Vergé et al., 2007, 2008a, 2008b, 2009). This concept set the limits of the livestock production systems and has been used to quantify the cropland not used to support livestock in Canada (Dyer, Vergé, Kulshreshtha, Desjardins, \& McConkey, 2011). It was used in the present study to describe both the area needed to grow the crops that feed all animals in the sheep and beef industries, as well as the GHG emissions caused by the production of those crops. The crop complex area includes both the roughage and grain crops in the animal diet. A relative comparison of areas in the Sheep Crop Complex (SCC) with the Beef Crop Complex (BCC) on the basis of five crop type groups is shown in Table 1. Corn silage was in a crop category by itself because it is both a roughage and an annual crop. In ULICEES, only improved pasture areas were considered in the GHG emission budgets because un-improved pasture does not receive any farm inputs (Vergé et al., 2012). The crop areas, shown in Table 1 as percent of all areas in each crop complex, were estimated from livestock diets using the ULICEES model.

Table 1. Livestock (LS) crop complexes of the sheep and beef industries in Eastern and Western Canada based on five different feed types during 2006

\begin{tabular}{ccccccc}
\hline $\begin{array}{c}\text { Feed } \\
\text { type }\end{array}$ & \multicolumn{2}{c}{$\begin{array}{c}\text { Annuals } \\
\text { Grain }\end{array}$} & $\begin{array}{c}\text { Alfalfa } \\
\text { Silage }\end{array}$ & $\begin{array}{c}\text { Other } \\
\text { hay }\end{array}$ & $\begin{array}{c}\text { Improved } \\
\text { pasture }\end{array}$ & $\begin{array}{c}\text { All crop } \\
\text { complex land }\end{array}$ \\
\cline { 2 - 7 } & \multicolumn{7}{c}{ \% of area in the crop complex of each LS type } \\
\cline { 2 - 7 } sheep & 7 & 2 & 40 & 33 & 18 & 100 \\
beef & 16 & 3 & 27 & 28 & 25 & 100 \\
\hline & \multicolumn{7}{c}{. } & & \multicolumn{5}{c}{ Eastern Canada } \\
sheep & 12 & 0 & 42 & 13 & 32 & 100 \\
beef & 21 & 0 & 29 & 14 & 36 & 100 \\
\hline
\end{tabular}

\subsubsection{Grain Crop}

As was done for the four previous complexes, the grain area in the SCC is the product of the sheep population, their diet and the yield of each feed grain, integrated over all grain crops in the sheep diet. Because Statistics Canada gives livestock rations for a whole year (Elward et al., 2003) these data give the total quantity of feed consumed during the life of market lambs that are younger than one year when slaughtered. The number of market lambs required to determine the annual GHG emissions budget must represent the average yearly population. Therefore, feed intake over the life of these short-lived animals was expanded to obtain the equivalent feed quantity over all sheep that lived during the full year. Rations were multiplied by the ratio of market lamb population slaughtered in 2006 (Statistics Canada, 2009) to the population of all living market lambs at the time of the 2006 agricultural census. The ratio for Canada was 1.92. This high ratio is a reflection of 
the lives of market lambs only being about 190 days, compared to a full year.

\subsubsection{Perennial Forages}

To estimate the area of perennial forage in the SCC, the provincial crop areas provided by Statistics Canada (2002) had to be partitioned among the dairy, beef and sheep populations. However, because there were no yield data collected for forage crops in Canada, the forage components of the SCC could not be calculated in the same way as the grain components. Since the harvest from this land was limited to fodder for sheep, beef or dairy cattle, the consumption amounts for each province, forage type and age-gender category (Elward et al., 2003) were used to partition the forage areas among these categories over each of the three ruminant livestock types. The four sources of roughage as defined by the Canadian agricultural census (Statistics Canada, 2002) include tame or seeded pasture, alfalfa and alfalfa mixes, corn silage and all other tame hay and fodder crops (Table 1).

\subsection{Animal Population and Production}

\subsubsection{Animal Populations}

Assessing all animal categories during one year would be equivalent to the complete life cycle of the meat produced in that year (Dyer, Vergé, Desjardins, Worth, \& McConkey, 2010b). Because ULICEES calculates GHG emissions separately for each age-gender category, the true carbon footprint of slaughtered lambs is defined by the GHG emissions from the whole sheep population. The three age-gender categories used to describe the sheep population are presented in Table 2. Rams were combined with ewes as one category because of the very small number of rams.

Table 2. Eastern and Western Canadian sheep populations by age-gender category recorded on July 1 for the 2006 census

\begin{tabular}{ccccc}
\hline & \multicolumn{4}{c}{ Head,000 } \\
\cline { 2 - 5 } Region & $\begin{array}{c}\text { Rams and } \\
\text { Ewes }\end{array}$ & $\begin{array}{c}\text { Replacement } \\
\text { lambs }\end{array}$ & $\begin{array}{c}\text { Market } \\
\text { lambs }\end{array}$ & $\begin{array}{c}\text { Total } \\
\text { population }\end{array}$ \\
\hline East & 369 & 52 & 164 & 584 \\
West & 234 & 41 & 164 & 439 \\
Canada & 602 & 93 & 328 & 1,023 \\
\hline
\end{tabular}

\subsubsection{Canadian Market Lamb Production}

The GHG emission intensity of Canadian sheep was based on the LW at the time of slaughter, rather than the average LW during its growing life span. Since the ideal market LW is 45 to $50 \mathrm{~kg}$ (BCMAL, 2013), $48 \mathrm{~kg}$ was used as a benchmark LW in the emission intensity estimates. Due to data limitations and the small size of the industry, we did not try to differentiate east-west market lamb LW. Since sheep farmers must cull their oldest ewes every year, $22 \%$ of the breeding ewes contribute to the carcasses going to market (Hale, Coffey, Bartlett, \& Ahrens, 2010), equivalent to an average of 4.5 reproductive years for the breeding ewe. In comparison, a six year breeding life was used for beef (Vergé et al., 2008a). The LW assumed for the culled ewes was $57 \mathrm{~kg}$ (Hale et al., 2010), while the LWs for slaughtered calves, heifers, steers and culled cows were as used in ULICEES (Vergé et al., 2012).

\subsubsection{Beef to Lamb Protein Differences}

The difference in GHG emission intensities between the beef industry and the sheep and lamb industry was assessed on the basis of protein supply. In this context, protein is taken to include only human edible protein (excluding blood meal, pet food, edible offal and leather). This comparison does not allow for potential nutritional differences between beef and lamb. The LW conversions to protein were $6.4 \%$ for slaughter lambs (Pouliot et al., 2009; USDA, 2009) and 8.3\% for slaughter steers and heifers (Dyer et al., 2010a; USDA, 2009).

\section{Results}

\subsection{Land Areas and Sheep Populations}

There are noticeable differences in the land use shown in Table 1 between the east and west for both the BCC and SCC. Silage is only fed in measurable quantities in Eastern Canada. The areas in the alfalfa mixes (third column) were almost $50 \%$ higher in the SCC than in the BCC in both regions. The harvested perennial forage 
(columns 3 and 4) accounted for relatively more area in the SCC than in the BCC in both the east and the west. The beef industry in the east used $40 \%$ more of its crop complex area as improved pasture land (fifth column) than the sheep industry, whereas this difference was only $11 \%$ in the west. Most importantly, in both the SCC and the BCC, Western Canada had appreciably more of its land base in feed grains (first column) than did Eastern Canada.

Table 2 shows that breeding sheep are just over half of the whole Canadian population, which is a reflection of the short lifespan of the slaughter lambs. Although these replacement lambs are not counted as breeding stock, these counts include rams which make up 5\% of the ewe population. In the 2006, July 1 census records, market lambs are more than two thirds of the ewe population in Western Canada, but are just under half of the ewe population in Eastern Canada. These lamb-to-ewe ratios are only a little lower than the marketing survey records shown in Figure 1 for July 1, 2006 (Statistics Canada, 2009). In Western Canada, the ewe population declined steadily by about $20 \%$ throughout the nine years, while in Eastern Canada, the ewe population did not start to decline until after 2004 (Figure 1). Overall, sheep populations are a little lower in the west than in the east, with a little over a million sheep in Canada (Table 2).

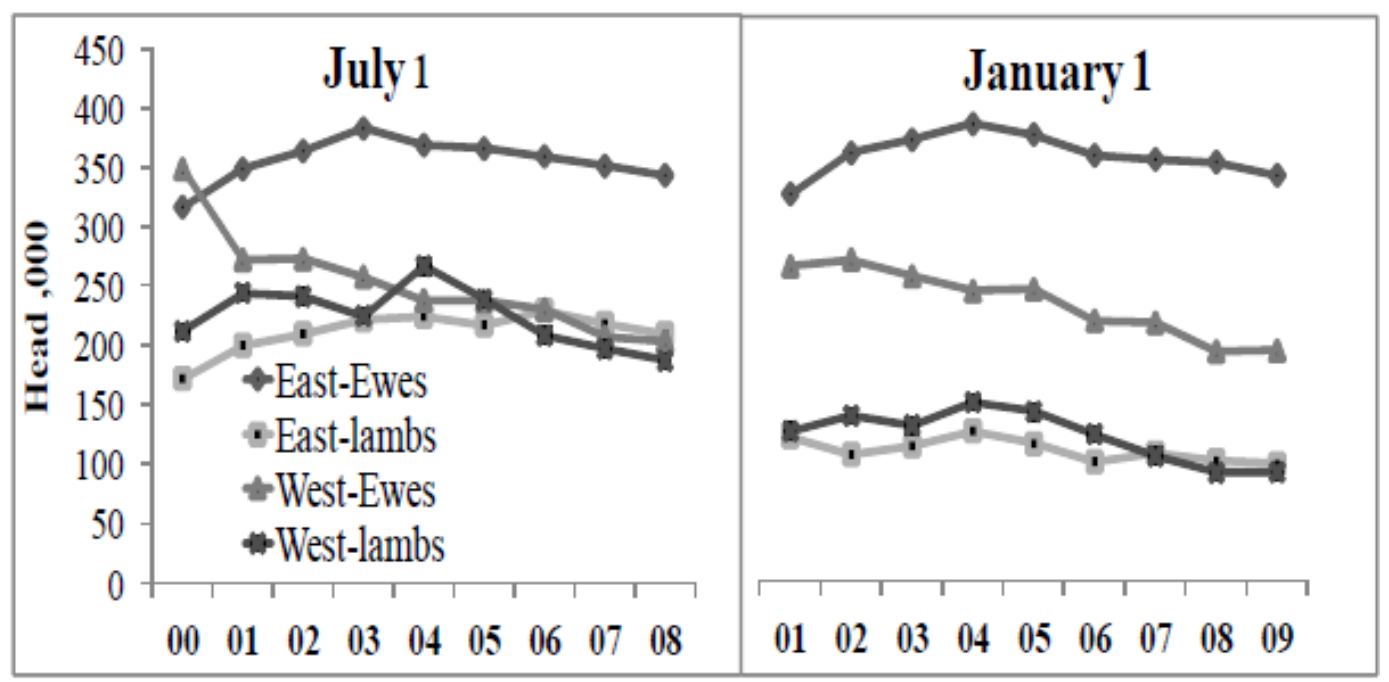

Figure 1. Breeding ewe and lamb populations over Eastern and Western Canada recorded on July 1 and January 1 between July, 2000 and January, 2009

The total GHG emission budgets for sheep and beef cattle are shown in Table 3. The proportion of $\mathrm{CH}_{4}, \mathrm{~N}_{2} \mathrm{O}$ and fossil $\mathrm{CO}_{2}$ emissions (in $\mathrm{CO}_{2} \mathrm{e}$ ) from sheep in Western Canada were 54\%, 35\% and 11\%, respectively, while for beef they were $60 \%, 28 \%$ and $12 \%$, respectively (Table 3 ). The distribution for beef was similar to the $58 \%, 33 \%$ and $9 \%$ distribution of these three GHGs reported for beef on an experimental farm in Alberta between 2008 and 2010 (Basarab et al., 2012). Due to the very small population, around 1 million head in 2006, GHG emissions from raising beef cattle were roughly two orders of magnitude higher than the GHG emissions from raising sheep (Table 3). For beef, the GHG emissions in the west were much higher than in the east, while the east-west distribution of GHG emissions for the sheep industry was consistent with the $60 \%$ to $40 \%$, east to west, sheep population split shown in Table 2. In the west the percentages of the total GHG emissions that $\mathrm{CH}_{4}$ emissions accounted for from the two industries were similar. The $\mathrm{CH}_{4}$ share of GHG emissions was slightly lower in the east for both industries. For sheep, as well as for eastern beef, $\mathrm{N}_{2} \mathrm{O}$ emissions exceeded fossil $\mathrm{CO}_{2}$ emissions by three and half times. 
Table 3. Greenhouse gas (GHG) emissions from the sheep and beef industries in Canada in 2006

\begin{tabular}{|c|c|c|c|c|c|c|c|c|}
\hline \multirow[b]{4}{*}{ East } & \multicolumn{8}{|c|}{$\mathrm{Tg} \mathrm{CO}_{2} \mathrm{e}$} \\
\hline & $\mathrm{CH}_{4}$ & $\mathrm{~N}_{2} \mathrm{O}$ & $\mathrm{CO}_{2}$ & Total GHG & $\mathrm{CH}_{4}$ & $\mathrm{~N}_{2} \mathrm{O}$ & $\mathrm{CO}_{2}$ & Total GHG \\
\hline & \multicolumn{4}{|c|}{ Sheep } & \multicolumn{4}{|c|}{ Beef } \\
\hline & 0.10 & 0.09 & 0.03 & 0.22 & 3.05 & 1.87 & 0.66 & 5.58 \\
\hline West & 0.07 & 0.05 & 0.01 & 0.13 & 18.10 & 8.07 & 1.82 & 27.99 \\
\hline Canada & 0.17 & 0.14 & 0.04 & 0.35 & 21.15 & 9.94 & 2.48 & 33.57 \\
\hline
\end{tabular}

\subsection{GHG Emission Intensity}

Table 4 shows the comparison of the sheep and lamb industry with the beef industry on the basis of the GHG emissions (in $\mathrm{CO}_{2} \mathrm{e}$ ) per weight of protein produced. In terms of protein based intensity, fossil $\mathrm{CO}_{2}$ and $\mathrm{CH}_{4}$ emissions from sheep exceeded those from beef cattle by 30\%. For the $\mathrm{N}_{2} \mathrm{O}$ emission intensity, the lamb intensity was 2.2 times as high as that of beef. For total GHG emission intensities, lamb production exceeded beef by factors of 1.31 in the east, 1.65 in the west and 1.65 for Canada. In both lamb and beef production, $\mathrm{CH}_{4}$ accounted for $50 \%$ to $60 \%$ of total emissions, while fossil $\mathrm{CO}_{2}$ accounted for $7 \%$ to $11 \%$ of the total and $\mathrm{N}_{2} \mathrm{O}$ accounted for $30 \%$ to $40 \%$ of the total. For lamb production, $\mathrm{CH}_{4}$ emission intensities as a share of the total GHG emissions were slightly lower than for beef, while the lamb $\mathrm{N}_{2} \mathrm{O}$ emission intensity share of its total was slightly higher. These differences reflect the differences in manure since differences between sheep and beef manure affects both $\mathrm{CH}_{4}$ and $\mathrm{N}_{2} \mathrm{O}$ emission rates. The spread between $\mathrm{CH}_{4}$ and $\mathrm{N}_{2} \mathrm{O}$ emission intensities was slightly higher in the west than in the east for both industries. This same pattern was seen in the total GHG emission beef-sheep comparisons (Table 3).

Table 4. Protein-based emission Intensity of $\mathrm{CH}_{4}, \mathrm{~N}_{2} \mathrm{O}$, fossil $\mathrm{CO}_{2}$, and total $\mathrm{GHG}$ from sheep and beef cattle in Eastern and Western Canada during 2006

\begin{tabular}{|c|c|c|c|c|c|c|c|c|}
\hline & \multicolumn{8}{|c|}{$\mathrm{kg} \mathrm{CO}_{2} \mathrm{e} / \mathrm{kg}$ protein } \\
\hline & $\mathrm{CH}_{4}$ & $\mathrm{~N}_{2} \mathrm{O}$ & $\mathrm{CO}_{2}$ & Total GHG & $\mathrm{CH}_{4}$ & $\mathrm{~N}_{2} \mathrm{O}$ & $\mathrm{CO}_{2}$ & Total GHG \\
\hline & \multicolumn{4}{|c|}{ Sheep } & \multicolumn{4}{|c|}{ Beef } \\
\hline East & 102 & 93 & 27 & 223 & 93 & 57 & 20 & 170 \\
\hline West & 113 & 73 & 21 & 207 & 81 & 36 & 8 & 126 \\
\hline Canada & 107 & 85 & 24 & 217 & 83 & 39 & 10 & 131 \\
\hline
\end{tabular}

The GHG emission intensity reported in the LCA for sheep in France (Gac, Ledgard, Lorinquer, Boyes, \& Le Gall, 2012) without an adjustment for the wool byproduct was $12.9 \mathrm{~kg} \mathrm{CO} 2 \mathrm{e} / \mathrm{kg} \mathrm{LW}$. Williams, Audsley, \& Sandars (2012) found the GHG emission intensity for lamb production in northern England to be $22 \mathrm{tCO}_{2} \mathrm{e} / \mathrm{t}$ edible carcass. Using the percents of carcass per LW and of carcass after fat trim presented for beef by Dyer et al. (2010a), this result was converted to $12.3 \mathrm{~kg} \mathrm{CO} 2 \mathrm{e} / \mathrm{kg} \mathrm{LW}$ (Figure 2). The GHG emission intensity for lamb production was found to be $12.9 \mathrm{~kg} \mathrm{CO}_{2} \mathrm{e} / \mathrm{kg} \mathrm{LW}$ in Wales (Edwards-Jones et al., 2009) and $10.0 \mathrm{~kg} \mathrm{CO}_{2} \mathrm{e} / \mathrm{kg} \mathrm{LW}$ for the extensive production system in Ireland (Casey \& Holden, 2005). The New Zealand (NZ) results reported by $\mathrm{Cac}$ et al. (2012) were $8.5 \mathrm{~kg} \mathrm{CO}_{2} \mathrm{e} / \mathrm{kg} \mathrm{LW}$. The much lower intensity was expected for NZ, due to warmer climatic conditions, year-round grazing in perennial pastures and no GHG emissions linked to the production of harvested feed and manure management.

The comparison of this paper with the emission intensities from sheep in other countries required that GHG emission intensities be expressed on a LW, rather than protein, basis. The gas-specific emission factors shown in Table 5 represent close to primary calculations within ULICEES. However, they could not be broken down to the per-number of head basis, because of weight and diet differences among the age-gender categories in each livestock type. Nor could they be broken down by area because the SCC involves three distinct types of land use (pasture, harvested perennial forage and annual feed crops). These emission factors are the components of the LW-based emission intensities for Canadian lambs shown in Figure 2. 
Table 5. GHG emission factors for sheep and beef cattle in Eastern and Western Canada during 2006 based intensity of emissions of $\mathrm{CH}_{4}, \mathrm{~N}_{2} \mathrm{O}$, and fossil $\mathrm{CO}_{2}$ per unit of $\mathrm{LW}^{1}$ of slaughter animals

\begin{tabular}{cccccccc}
\hline & \multicolumn{6}{c}{$\mathrm{kg} \mathrm{CO}_{2} \mathrm{e} / \mathrm{kg} \mathrm{LW}$} \\
\cline { 2 - 4 } \cline { 6 - 8 } Region & $\mathrm{CH}_{4}$ & $\mathrm{~N}_{2} \mathrm{O}$ & $\mathrm{CO}_{2}$ & & $\mathrm{CH}_{4}$ & $\mathrm{~N}_{2} \mathrm{O}$ & $\mathrm{CO}_{2}$ \\
\cline { 2 - 4 } \cline { 6 - 8 } & \multicolumn{3}{c}{ Sheep } & & \multicolumn{4}{c}{ Beef } \\
\hline East & 6.5 & 6.0 & 1.7 & & 7.7 & 4.7 & 1.7 \\
West & 7.3 & 4.6 & 1.3 & & 6.7 & 3.0 & 0.7 \\
\hline
\end{tabular}

${ }^{1} \mathrm{LW}=$ Live Weight of slaughter animals.

The average GHG emission intensity of lambs from Table 4 (based on $6.4 \%$ protein/LW) was $13.9 \mathrm{~kg} \mathrm{CO} \mathrm{CO}_{2} \mathrm{e} / \mathrm{kg}$ $\mathrm{LW}$ for Canada, $14.2 \mathrm{~kg} \mathrm{CO} \mathrm{e} / \mathrm{kg} \mathrm{LW}$ for the east, and $13.2 \mathrm{~kg} \mathrm{CO} \mathrm{CO}_{2} \mathrm{e} / \mathrm{kg} \mathrm{LW}$ for the west (Figure 2). The Canada-wide LW based GHG emission intensity for lambs exceeded the English and French LW based emission intensities by $13 \%$ and $7 \%$, respectively. The emission intensity of the Canadian sheep industry was almost double that of the New Zealand sheep industry. Using $8.3 \%$ protein for slaughter steers and heifers, the average Canadian GHG emission intensity of beef from Table 4 was $11.6 \mathrm{~kg} \mathrm{CO}_{2} \mathrm{e} / \mathrm{kg} \mathrm{LW}$. For the eastern and western beef industries, the intensities were $14.2 \mathrm{~kg} \mathrm{CO}_{2} \mathrm{e} / \mathrm{kg} \mathrm{LW}$ and $11.2 \mathrm{~kg} \mathrm{CO}_{2} \mathrm{e} / \mathrm{kg} \mathrm{LW}$, respectively. In their LCA for sheep, Gac et al. (2012) proposed two adjustment factors for the wool byproduct in the carbon footprint of lamb production in France. The reduction factor based on economic allocation was considered negligible, at $0.3 \%$, in France, given the low global value of wool. However, if the reduction factor based on mass allocation in France, $10.4 \%$, was applied to the Canadian lamb industry, the GHG emission intensity of lambs would be reduced to $12.4 \mathrm{~kg} \mathrm{CO} 2 \mathrm{e} / \mathrm{kg} \mathrm{LW}$ for Canada.

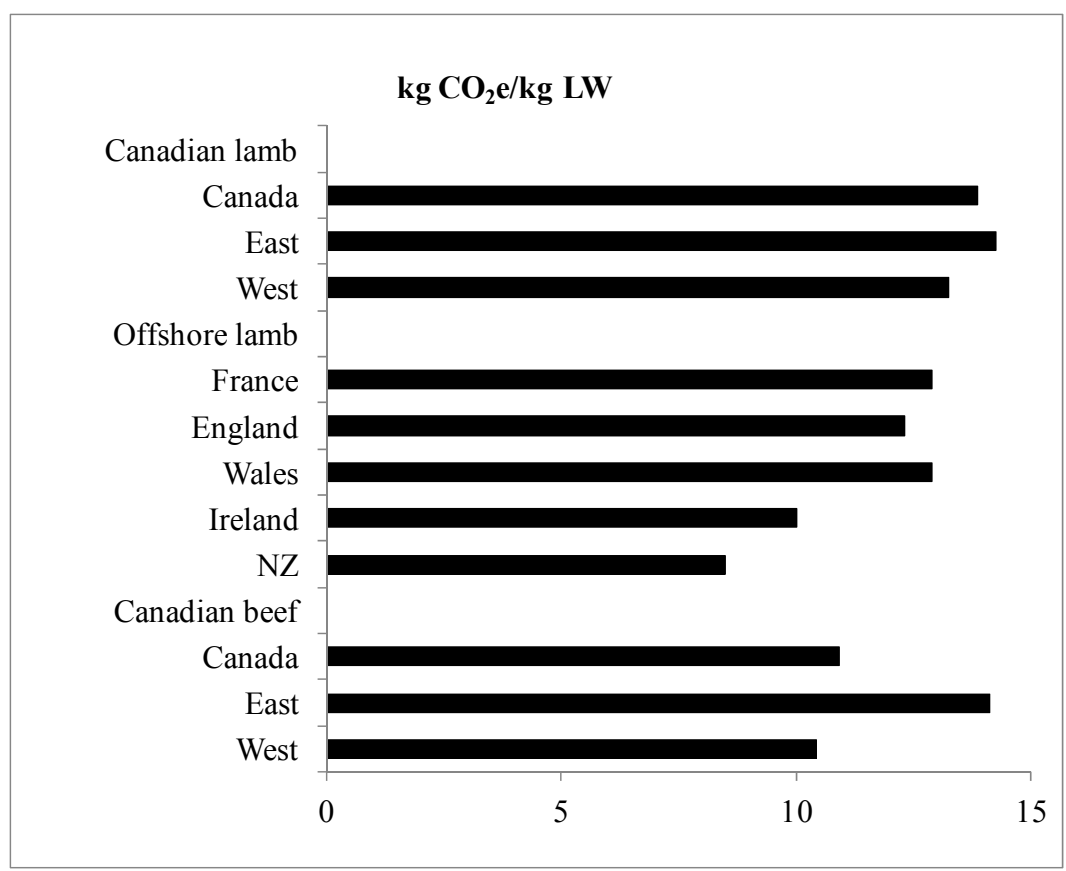

Figure 2. Comparisons of the GHG emission intensities of Canadian beef, lamb and offshore lamb, including France, England, Wales, Ireland and New Zealand (NZ), on the basis of live weight (LW) production for 2006

\section{Discussion}

The high ratios of ewes and rams to replacement lambs in Table 2 suggest that the reproductive lifespan of a ewe is about 6 years in Canada which is appreciably longer than the 4.3 year lifespan reported by Williams et al. (2012) or the 4.5 years suggested by Hale et al. (2010). Rather than a 6 year breeding life, however, it is more likely that Statistics Canada has miscounted the age-gender categories of sheep. For example, replacement ewe-lambs which have not yet given birth or ewes that are soon destined for slaughter as culls may both have 
been counted as breeding ewes. The margin by which breeding sheep (rams and ewes) outnumbered the combined replacement and slaughter lambs was $70 \%$ in the east and $10 \%$ in the west based on the 2006 census data. Also, the ratio of rams and ewes to the replacement lambs in Table 2 is higher in the east. These east-west differences are consistent with Figure 1.

Even though the sheep GHG emission intensities generated by ULICEES (Figure 2) exceeded the French and English sheep industries, these differences were considered to be reasonably close. The higher Canadian GHG intensities are partly due to the more severe climate in Canada. They were also partly due to the intensive production system used in Canada compared to the offshore lamb industries (Edwards-Jones et al., 2009), particularly Ireland. Figure 2 suggests that beef from Eastern Canada has a higher carbon footprint than lamb from the five offshore lamb industries that were compared here. However, due to the differences in protein to LW ratios, emission intensity estimates based on LW mask 33\% of the difference between Canadian lamb and beef based on edible protein. Hence, the differences seen in Table 4 give a more realistic comparison of eastern Canadian beef to offshore lamb than shown in Figure 2.

The east-west differences in GHG emissions and emission intensities for both the sheep and beef industries (Tables 3 and 4) were mainly due to higher $\mathrm{N}_{2} \mathrm{O}$ emissions related to the more humid conditions and wetter soils in Eastern Canada (Desjardins et al., 2012; Rochette et al., 2008). While they were not allowed for in this analysis, the age and weight of lambs before slaughter, fecundity and breed, may be possible sources of east-west differences. However, with the market for Canadian wool being so low, there is no incentive for Canadian sheep farmers to choose breeds based on wool production rather than meat (Hosford, 2007; Stewart, personal communication).

The sheep and lamb industry in Canada is very small relative to the sheep industries in England and France (Walker, 2008) and in comparison to the Canadian beef industry (Table 2). It is dispersed over large areas dominated by other farm types. Consequently, it is not surprising that the data on sheep breeds and management needed to make in depth regional comparisons have not been gathered in Canada. Being a small industry dispersed over long distances and a range of climates, wide variances should be expected on the mean Canadian GHG emissions presented in this paper.

The agreement with the distribution of emissions over the three GHGs between the estimated western beef industry (Table 3) with the measured emissions from the beef herd on the Alberta experimental farm was reasonably close. This indirect verification for the beef component of ULICEES, even though it was limited to one site, provided some confidence in the value of ULICEES as a tool for this analysis. The east-west difference in the GHG emissions from the beef industry is consistent with GHG emission assessment reported by Desjardins et al. (2012). Whether using rangeland to graze sheep is sustainable would depend on a range of ecological factors as well as GHG emissions, and all of these factors must be considered in evaluating this land use policy.

\section{Conclusion}

Perhaps the most surprising aspect of the current Canadian sheep industry was its intensive production practices and the relatively high dependence on grains in the sheep diet. With the GHG emission intensity of the current sheep industry exceeding that of beef throughout Canada and for all three GHGs (Tables 4 and 5), there appears to be little benefit in expanding the sheep industry under the current grain dependent production system in either Eastern or Western Canada, at least from the perspective of the livestock carbon footprint. Differences in the foraging habits of sheep and cattle may mean some ecological benefits in grazing sheep that should be explored. Although the protein basis of comparison was more dramatic, both the LW and protein based GHG emission intensity indicators show the disadvantage of relying on lamb as a protein source, compared to beef.

For more accurate assessment of the role that sheep should play in the Canadian livestock industries, a repeat of the 2001 diet survey of all livestock types (Elward et al., 2003) is needed. The increasing availability of biofuel feedstock byproducts can do much to increase dietary energy and protein and reduce the carbon footprints of all livestock commodities in Canada. This new form of land use adds further incentive to update the livestock diet information base across Canada.

The next step following the research recommended above will be an LCA which would include all of the processing of the meat (lamb), offal, hide and wool products and byproducts. While ULICEES is not an LCA model, it has been interfaced with an LCA for the carbon footprint of the dairy industry (Vergé et al., 2013) and has been applied to an LCA of the vertical integration of the beef industry (Desjardins et al., 2012). Although they were beyond the scope of this paper, ecological and social values need to be integrated with the GHG emission estimates in this LCA. The ULICEES model and the results shown in this paper would provide a basis 
for an LCA of Canadian lamb production. As the field monitoring research and data upgrades proposed above progress, sensitivity analysis should be done on the ranges in the terms that go into the ULICEES estimates of the GHG emissions from sheep and lambs in Canada.

While both economic and mass allocation would have to be investigated for dealing with wool on an international scale, the very low economic value of this byproduct in France (Gac et al., 2012) and the growing preference for breeds that shed their fleece (Walker, 2008) effectively eliminates wool from the carbon footprint of the lamb industry, at least in Canada. Since the market demand for wool is almost gone, economics was the more meaningful byproduct allocation for both the Canadian and French sheep industries. A more important justification than wool for continued support of lamb production in Canada would be the ability of sheep to digest plant types that are unsuitable as cattle feed, and in some cases (such as leafy spurge) are toxic to cattle. The role that sheep in concert with cattle could play in making sustainable use of rangeland, where a range of plant species must be allowed to grow, should be investigated as a land use policy in Western Canada. This policy, however, would be a departure from the current intensive approach to lamb production. Whether using rangeland to graze sheep is sustainable would depend on a range of ecological factors as well as GHG emissions, and all of these factors must be considered in evaluating this land use policy.

\section{References}

ASAE. (2003). Manure Production and Characteristics - D384.1 FEB03- 4p. American Society of Agricultural and Biological Engineers (ASAE), St. Joseph, MI, USA.

Basarab, J., Baron, V., López-Campos, Ó., Aalhus, J., Haugen-Kozyra, K., \& Okine, E. (2012). Greenhouse Gas Emissions from Calf- and Yearling-Fed Beef Production Systems, With and Without the Use of Growth Promotants. Animals, 2, 195-220. http://dx.doi.org/10.3390/ani2020195

BCMAL. (2013). Sheep - How are sheep produced? British Columbia Ministry of Agriculture (BCMAL). Province of British Columbia. Retrieved from http://www.agf.gov.bc.ca/aboutind/products/livestck/sheep.htm

Beauchemin, K. A., Janzen, H. H., Little, S. M., McAllister, T. A., \& McGinn, S. M. (2010). Life cycle assessment of greenhouse gas emissions from beef production in western Canada: A case study. Agricultural Systems, 103, 371-379. http://dx.doi.org/10.1016/j.agsy.2010.03.008

Bonatti, M., Schlindwein, S. L., de Vasconcelos, A. C. F., Sieber, S., D'Agostini, L. R., Lana, M. A., ... Canci, A. (2013). Social organization and agricultural strategies to face climate variability: A case study in Guaraciaba, Southern Brazil. Sustainable Agriculture Research, 2(3), 118-125. http://dx.doi.org/10.5539/sar.v2n3p118

CAEEDAC. (2001). A Review of the 1996 Farm Energy Use Survey (FEUS). A Report to Natural Resources Canada (NRCan) by The Canadian Agricultural Energy End-Use Data Analysis Centre (CAEEDAC). Retrieved from http://www.usask.ca/agriculture/caedac/pubs/pindex.htm

Casey, J. W., \& Holden, N. M. (2005). Holistic analysis of GHG emissions from Irish livestock production systems. Paper No. 054036. St. Joseph, MI, American Society of Agricultural and Biological Engineers. Retrieved from https://elibrary.asabe.org/azdez.asp?AID=19478\&T=2

Capper, J. L. (2012). Is the Grass Always Greener? Comparing the environmental impact of conventional, natural and grass-fed beef production systems. Animals, 2, 127-143. http://dx.doi.org/10.3390/ani2020127

CCWG. (2011). Canada's wool to market. Canadian Cooperative Wool Growers Ltd. (CCWG). Retrieved from http://www.wool.ca/about_wool

Cottle, D. J., Nolan, J. V., \& Wiedemann, S. G. (2011). Ruminant enteric methane mitigation: a review. Animal Production Science, 51(6), 491-514. http://dx.doi.org/10.1071/AN10163

Desjardins, R. L., Worth, D. E., Vergé, X. P. C., Maxime, D., Dyer, J., \& Cerkowniak, D. (2012). Carbon Footprint of Beef Cattle. Sustainability, 4, 3279-3301. http://dx.doi.org/10.3390/su4123279

Dyer, J. A., \& Desjardins, R. L. (2009). A review and evaluation of fossil energy and carbon dioxide emissions in Canadian agriculture. J. Sustain. Agric., 33(2), 210-228. http://dx.doi.org/10.1080/10440040802660137

Dyer, J. A., Desjardins, R. L., McConkey, B. G., Kulshreshtha, S., \& Vergé, X. P. C. (2013). Integration of farm fossil fuel use with local scale assessments of biofuel feedstock production in Canada. Chapter 4; In Biofuel Economy, Environment and Sustainability (pp. 97-122). Zhen Fang (Ed.) InTech Open Access Publisher. Rijeka, Croatia.

Dyer, J. A., Vergé, X. P. C., Desjardins, R. L., \& Worth, D. (2008). Long-term trends in the greenhouse gas 
emissions from the Canadian dairy industry. Can. J. Soil Sci., 88, 629-639. http://dx.doi.org/10.4141/CJSS07042

Dyer, J. A., Vergé, X. P. C., Desjardins, R. L., \& Worth, D. E. (2010a). The Protein-based GHG Emission Intensity for Livestock Products in Canada, J. Sustain. Agric., 34(6), 618-629. http://dx.doi.org/10.1080/10440046.2010.493376

Dyer, J. A., Vergé, X. P. C., Desjardins, R. L., Worth, D. E., \& McConkey, B. G. (2010b). Understanding, Quantifying and Reporting Greenhouse Gas Emissions from Canadian Farmland. Sustainable Futures: The official publication of the Agricultural Institute of Canada, (pp. 10, 12).

Dyer, J. A., Vergé, X. P. C., Kulshreshtha, S. N., Desjardins, R. L., \& McConkey, B. G. (2011). Residual crop areas and greenhouse gas emissions from feed and fodder crops that were not used in Canadian livestock production in 2001. J. Sustain. Agric., 35(7), 780-803. http://dx.doi.org/10.1080/10440046.2011.606493

Edwards-Jones, G., Plassmann, K., \& Harris, I. M. (2009). Carbon footprinting of lamb and beef production systems: insights from an empirical analysis of farms in Wales, UK. Journal of Agricultural Science, 147, 707-719. http://dx.doi.org/10.1017/S0021859609990165

Elward, M., McLaughlin, B., \& Alain, B. (2003). Livestock Feed Requirements Study 1999-2001. Catalogue No. 23-501-XIE, Statistics Canada, p. 84.

Gac, A., Ledgard, S., Lorinquer, E., Boyes, M., \& Le Gall, A. (2012). Carbon footprint of sheep farms in France and New Zealand and methodology analysis. In 8th International Conference on LCA in the Agri-food Sector, Parallel Session 3C: Sheep and Dairy Production Systems. Saint Malo, France.

Hale, M., Coffey, L., Bartlett, A., \& Ahrens, C. (2010). Sustainable and Organic Production, A project of the National Center for Appropriate Technology (NCAT), National Sustainable Agriculture Information Service. Retrieved from http://www.cultivatingsuccess.org/instructors/SSFR\%20Readings\%202011/9.5_Sust_Sheep.pdf

Hosford, S. (2007). Wool Marketing in Canada. Agriculture and Rural Development (ARD) of Alberta. Retrieved from http://www1.agric.gov.ab.ca/\$department/deptdocs.nsf/all/sis11784

IPCC. (2006). Intergovernmental Panel on Climate Change. Guidelines for National Greenhouse Gas Inventories. Volume 4: Agriculture, Forestry and Other Land Use. Chapter 10: Emissions from Livestock and Manure Management. Retrived from http://www.ipcc-nggip.iges.or.jp/public/2006gl/index.htm

Janzen, H. H., Desjardins, R. L., Rochette, P., Boehm, M., \& Worth, D. (Eds). (2008). Better Farming Better Air. Agriculture and Agri-food Canada (p. 151). Ottawa, Ontario, Canada.

Marinier, M., Clark, K., \& Wagner-Riddle, C. (2004). Improving estimates of methane emissions associated with animal waste management systems in Canada by adopting an IPCC Tier 2 methodology. Technical Report, p. 30. University of Guelph.

OMAFRA. (2011). Grazing Management: Animals as Grazers, Publication 19, Pasture Production, Chapter 4; Ontario Ministry of Agriculture, Food and Rural Affairs (OMAFRA). Retrieved from http://www.omafra.gov.on.ca/english/crops/pub19/4grazers.htm

Pouliot, E., Garie, C., Theriault, M., Avezard, C., Fortin, J., \& Castonguay, F. W. (2009). Growth performance, carcass traits and meat quality of heavy lambs reared in a warm or cold environment during winter. Can. $J$. Anl. Sci., 229-239.

Rochette, P., Worth, D. E., Lemke, R. L., McConkey, B. G., Pennock, D. J., Wagner-Riddle, C., \& Desjardins, R. L. (2008). Estimation of $\mathrm{N}_{2} \mathrm{O}$ emissions from agricultural soils in Canada - Development of a country-specific methodology. Can. J. Soil Sci. (Special edition), 88, 641-654. http://dx.doi.org/10.4141/CJSS07301

SMA. (2008). Reducing Leafy Spurge's Impact By Using Sheep and Goats, Government of Saskatchewan, Saskatchewan Ministry of Agriculture (SMA). Retrieved from http://www.agriculture.gov.sk.ca/Default.aspx?DN=7984b1a8-5088-4068-a7d4-024f5837e240, Accessed 10 May 2013.

Statistics Canada. (2002). Agricultural Census 2001, Cat. No 95F0301XIE.

Statistics Canada. (2003). Livestock feed requirements study, 1999-2001, Cat. No 23-501-XIE.

Statistics Canada. (2009). Sheep Statistics, vol. 8 no. 1, Cat. No. 23-011-X. p. 30. 
Stewart, D. W. personal communication. worked as an research scientist in the Research Branch of Agriculture and Agri-food Canada from 1977 to 2002; now a sheep farmer in Eastern Ontario.

USDA. (2009). National Nutrient Database for Standard Reference, Release 21 Protein (g) Content of Selected Foods per Common Measure, sorted alphabetically - p. 25 USDA. Retrieved from http://www.ars.usda.gov/Services/docs.htm?docid=8964

Van Dyne, G. M., Brockington, N. R., Sxocs, Z., Duek, J., \& Ribic, C. A. (1980). Large herbivore sub-systems. In In A. I. Breymeyer \& G. M. Van Dyne (Eds.) Grasslands, systems analysis and man. (pp. 269-537). Cambridge, England: Cambridge University Press.

Vergé, X. P. C., Dyer, J. A., Desjardins, R. L., \& Worth, D. (2007). Greenhouse gas emissions from the Canadian dairy industry during 2001. Agricult. Sys., 94(3), 683-693.

Vergé, X. P. C., Dyer, J. A., Desjardins, R. L., \& Worth, D. (2008a). Greenhouse gas emissions from the Canadian beef industry. Agricult. Sys., 98(2), 126-134.

Vergé, X. P. C., Dyer, J. A., Desjardins, R. L., \& Worth, D. (2008b) Greenhouse gas emissions from the Canadian pork industry. Livest. Sci., 121, 92-101. http://dx.doi.org/10.1016/j.livsci.2008.05.022

Vergé, X. P. C., Dyer, J. A., Desjardins, R. L., \& Worth, D. (2009). Long-term trends in greenhouse gas emissions from the Canadian poultry industry. $J$. appl. Poult. Res., 18, 210-222. http://dx.doi.org/10.3382/japr.2008-00091

Vergé, X. P. C., Dyer, J. A., Worth, D. E., Smith, W. N., Desjardins, R. L., \& McConkey, B. G. (2012). A greenhouse gas and soil carbon model for estimating the carbon footprint of livestock production in Canada. Animals, 2, 437-454. http://dx.doi.org/10.3390/ani2030437

Vergé, X. P. C., Maxime, D., Dyer, J. A., Desjardins, R. L., Arcand, Y., \& Vanderzaag, A. (2013). Carbon footprint of Canadian dairy products Calculations and issues. Journal of Dairy Science, 96(9), 6091-6104. http://dx.doi.org/10.3168/jds.2013-6563

Walker, C. (2008). Easier managed sheep and beef cattle; simplified, profitable and productive sheep and beef farming. A Nuffield Farming Scholarships Trust Report. Sponsored by the Royal Highland Agricultural Society of Scotland and the Royal Smithfield Club. Retrieved from http://www.nuffieldinternational.org/rep_pdf/1253801058C_H_Walker_Nuffield_Report_read_only.pdf

Walker, J. W., Coffey, L., \& Faller, T. (2006). Improving Grazing Lands with Multi-Species Grazing. In A. Peischel \& D. D. Jr. Henry (Ed.). Targeted Grazing: A Natural Approach to Vegetation Management and Landscape Enhancement (pp. 50-55). Retrived from www.cnr.uidaho.edu/rx-grazing/Handbook.htm

Williams, A., Audsley, E., \& Sandars, D. (2012). A systems-LCA model of the stratified UK sheep industry. In 8th International Conference on LCA in the Agri-food Sector, Parallel Session 3C: Seep and Dairy Production Systems. Saint Malo, France.

\section{Copyrights}

Copyright for this article is retained by the author(s), with first publication rights granted to the journal.

This is an open-access article distributed under the terms and conditions of the Creative Commons Attribution license (http://creativecommons.org/licenses/by/3.0/). 